\title{
KESANTUNAN TUTURAN DALANG TEGALAN DALAM LIMBUKAN PADA PEMENTASAN WAYANG PURWA
}

\author{
Fauziah $^{* 1}$ dan Dewi Riyani ${ }^{2}$ \\ ${ }^{1,2}$ Pascasarjana Universitas Negeri Semarang \\ e-mail: *1 poyafauziah3@gmail.com
}

\begin{abstract}
ABSTRAK
Penelitian ini diberi judul "Kesantunan Tuturan Dalang Tegalan dalam Limbukan pada Pemenetasan Wayang Purwa”. Penelitian ini bertujuan untuk menganalisis: (1) pelanggaran prinsip kesantunan tuturan dalang tegalan dalam limbukan pada pementasan wayang purwa, (2) pematuhan prinsip kesantunan tuturan yang digunakan dalang tegalan dalam limbukan pada pementasan wayang purwa, dan (3) strategi kesantunan yang digunakan dalam tuturan dalang tegalan dalam limbukan pada pementasan wayang purwa. Penelitian ini merupakan penelitian kualitatif deskriptif. Teknik pengumpulan data dengan teknik simak dan catat. Data dalam penelitian ini berupa tuturan yang diduga mematuhi dan melanggar kesantunan berbahasa beserta konteksnya, dan tuturan tersebut nantinya akan ditranskripsi ke dalam bentuk tulisan. Hasil penelitian menunjukkan, terdapat pelanggaran prinsip kesantunan oleh Dalang Tegalan dalam limbukan pada pementasan wayang purwa antara lain pada bidal: (1) ketimbangrasaan, (2) keperkenaan, dan (3) kerendahatian. Pematuhan prinsip kesantunan oleh Dalang Tegalan dalam limbukan pada pementasan wayang purwa antara lain pada bidal : (1) kemurahhatian, (2) keperkenaan, dan (3) kerendahhatian. Strategi kesantunan yang dilakukan Dalang Tegalan antara lain: (1) kurmat, (2) andhap asor, dan (3) empan papan.
\end{abstract}

Kata kunci: kesantunan, dalang tegalan, limbukan.

\begin{abstract}
This research is about “The Politeness of Tegalan Puppet Master Speech in Limbukan on Shadow Puppet Performance". The objective of this research is to analyze: (1) violation of the principle of politeness of Tegalan puppet master in limbukan on shadow puppet performances, (2) adherence of politeness principle used by Tegalan puppet master in limbukan on shadow performances, and (3) politeness strategy used in speech Tegalan puppet master in limbukan on shadow puppet performances. This research is descriptive qualitative research. Techniques of collecting data premises techniques refer and record. The data in this research is a speech that allegedly obey and violate the politeness of language and its context, and the speech will be transcribed into written form. The result of the research shows that there is violation of the principle of politeness by Tegalan puppet master in limbukan on shadow puppet, among others on maxim: (1) tact, (2) approbation, and (3) modesty. Adherence to the principle of politeness by Tegalan puppet master in limbukan on shadow puppet performances, among others on maxim: (1) generosity, (2) approbation, and (3) modesty. The strategy of politeness done Tegalan puppet master, among others: (1) kurmat, (2) andhap asor, and (3) empan papan.
\end{abstract}

Keywords: politeness, tegalan puppet master, limbukan.

\section{PENDAHULUAN}

Dalam setiap berkomunikasi bahasa memegang peranan penting sebagai interaksi dalam kehidupan sosialnya. Sebagai alat komunikasi, bahasa merupakan saluran perumusan maksud seseorang melahirkan perasaan, dan kemungkinan menciptakan kerjasama dengan semua orang. Ada dua pihak yang terlibat dalam berbahasa, yaitu pengirim pesan (sender) dan penerima pesan (receiver). Setiap proses komunikasi bahasa dimulai dengan si pengirim merumuskan terlebih dahulu yang ingin diujarkan dalam suatu kerangka. Penggunaan bahasa yang baik dan santun dapat mencerminkan kepribadian seseorang sehingga dinilai baik oleh masyarakat.

Secara umum wayang purwa adalah jenis kesenian tradisi yang dilakukan oleh dalang dengan boneka wayang sebagai sarana utama. Pertunjukan wayang adalah merupakan warisan leluhur yang telah mampu bertahan hidup selama berabad-abad. Pertunjukan wayang selain 
terkandung nilai-nilai budaya yang bersifat universal, dan juga harus mau berkembang sesuai dengan keadaan yang mengiringi kehidupan wayang tersebut.

Secara konvensional, urutan adegan pertunjukan wayang terbagi menjadi tiga bagian pokok, yaitu pathet nem 'babak pertama', pathet sanga 'babak kedua' dan pathet manyura 'babak terakhir'. Babak pertama terdiri atas: a) adegan jejer 'adegan pertama', b) babak unjal 'kedatangan tamu pada adegan pertama', c) bedholan 'pelukisan usainya adegan pertama yang ditandai dengan keluarnya seluruh wayang yang hadir dari kelir', d) gapuran 'adegan raja menikmati keindahan pintu gerbang yang menuju ke tempat peristirahatan permaisuri dan atau para puteri keraton', e) kedhatonan 'adegan pertemuan raja dengan permaisuri' dilanjutkan adegan limbukan, f) paseban jawi 'adegan setelah limbukan para petinggi negara mengulangi inti pembicaraan pada jejer', g) budhalan 'keberangkatan para petinggi negara beserta para prajurit' dilanjutkan pocapan kereta (gajah) 'pelukisan atau narasi tentang kereta (gajah)' atau perang ampyak 'adegan para prajurit bekerja sama memperbaiki jalan', h) adegan sabrangan 'adegan raja seberang yang biasanya sebagai musuh raja pada jejer ', dan i) perang gagal 'adegan perang pada babak pertama antara bala tentara pada adegan jejer melawan sabrangan'.

Pada kira-kira tengah malam, dilanjutkan dengan pathet sanga 'babak kedua' yang terbagi dalam: a) adegan pathet sanga pisan 'adegan pertama pada bagian kedua', menyajikan adegan pertapan atau alas 'adegan kesatria dan panakawan mengunjungi seorang pendeta di pertapaan atau kesatria bersama punakawan sedang berkelana di hutan', b) adegan perang kembang 'perang pada babak kedua' biasanya kesatria melawan raksasa atau harimau, c) adegan sintren 'adegan kedua pada babak kedua', dan d) adegan perang sampak tanggung 'perang setelah adegan kedua pada babak kedua'.

Kemudian kira-kira jam tiga pagi mulai menapak pathet manyura 'babak yang terakhir yang terdiri atas: a) adegan manyura pisan 'adegan pertama pada babak terakhir', b) adegan manyura pindho 'adegan kedua pada babak terakhir', c) adegan manyura katelu 'adegan ketiga pada babak terakhir', d) perang brubuh 'perang menjelang akhir pergelaran wayang' dan dilanjutkan tayungan 'tarian kemenangan (biasanya oleh Bima)', e) golekan 'adegan penutup dengan pertunjukan tari wayang puteri yang terbuat dari kayu', dan dilanjutkan tancep kayon 'menancapkan wayang kayon di tengah sebagai pertanda usainya pertunjukan wayang'.

Kedudukan dalang dalam adegan limbukan dalam pertunjukan wayang di antaranya merupakan penghibur, yaitu setelah penonton menikmati adegan dialog pada adegan jejer yang bersifat lebih serius, dengan adegan limbukan para penonton diajak masuk ke dalam situasi yang lebih santai guna mengendorkan ketegangan. Pada umumnya pesan-pesan diketengahkan dengan bentuk tuturan yang lebih mudah dicerna, lugas, mudah dipahami dan disampaikan secara jenaka. Berhubung fungsi adegan limbukan merupakan adegan selingan, maka media ini cenderung sebagai ajang kreativitas dan spontanitas bagi dalang dalam rangka memuaskan penonton lewat humornya yang berkaitan dengan situasi kondisi saat pertunjukan itu berlangsung. Terkadang humor yang spontan ini melanggar prinsip kesantunan seperti dalam percakapan berikut.

Gareng: Sakdurunge nembang kok wis dicela...

Dalang: yo ben perkenalan biografine disik

Gareng: Sebelah kanan kok suarane gedhe-gedhe.

Marwoto : Namine sinten mbak?

Sinden 1: Nami kula Puji Lestari..

Marwoto: Taksih sinau?

Sinden 1: Nembe ajeng lulus.

Marwoto: Pendhet napa?

Sinden 1: Karawitan.

Gareng: Sing dipendhet napa mawon?

Sinden 1: Sedaya.

Gareng : Murka!

Percakapan di atas melanggar prinsip kesantunan yaitu bidal keperkenaan. Tuturan Gareng mempunyai implikatur keirihatian kepada sinden I. Selain pelanggaran prinsip kesantunan di atas, terkadang limbukan juga menjadi media bagi dalang untuk menyampaikan 
nasihat. Hal ini berarti selain ada pelanggaran prinsip kesantunan, dalam limbukan juga terdapat pematuhan prinsip kesantunan. Hal ini yang melatarbelakangi peneliti tertarik untuk melakukan penelitian dengan mengambil topik Kesantunan Tuturan Dalang tegalan dalam Limbukan pada Pementasan Wayang Purwa.

Tulisan tentang kesantunan berbahasa dengan judul "Pengaruh Usia dan Strategi Berbahasa: Pragmatik tentang Kesantunan Berbahasa pada Para Penutur Bahasa Indonesia". Penelitian ini bertujuan melihat pengaruh variabel usia ini dalam kaitannya dengan realisasi kesantuanan berbahasa. Data diambil melalui sebuah penelitian dengan menggunakan kuesioner sebagai instrumennya, wawancara dan observasi langsung juga dilakukan. Kuesioner isian ini disebut dengan DCT (Discourse Completion test). 250 pasang kuesioner disebar (DCT A dan DCT B) di kota Singaraja pada kelompok usia antara 18-65 tahun. Penelitian ini menemukan antara lain, pertama, ada perbedaan realisasi kesantunan berbahasa yang sangat kentara diantara para responden dari berbagai generasi. Kedua, variabel usia dapat dinayatakan sebagai variabel sosial yang tidak hanya bersifat instrumental tapi lebih dari itu yaitu bersifat fungsional. Hal ini ditunjukkan oleh temuan penelitian ini dimana variabel usia memiliki bobot yang lebih tinggi dan mengontrol variabel sosial yang lainnya seperti jender, status sosial, jarak sosial dan lain-lain. Tidak adanya faktor usia pada rumusan Brown dan Levinson (1987) dapat dipahami karena pada budaya mereka (barat) faktor usia tidak memiliki perananan yang signifikan untuk menentukan tingkat kesantunan berbahasa seseorang. Pandangan budaya timur yang berbeda dengan budaya barat rupanya harus dipandang sebagai suatu hal yang penting untuk mengubah pandangan Brown dan Levinson diatas. Melalui penelitian ini, disarankan agar variabel usia mendapat perlakuan yang layak dan proporsional, ada baiknya ketika merumuskan tingkat kesantunan sebuah pertuturan variabel usia juga ada di dalamnya [1].

Tulisan tentang kesantunan berbahasa dengan judul "Kesantunan Berbahasa dalam Tuturan Novel Para Priyayi Karya Umar Kayam" yang dimuat dalam Jurnal Seloka Unnes. Tujuan dari penelitian Alviah ini meliputi tiga hal: (1) mendeskripsi dan mengidentifikasi tuturan yang muncul dalam novel Para Priyayi karya Umar Kayam; (2) mendeskripsi karakteristik tuturan dalam Para Priyayi karya Umar Kayam guna mewujudkan kesantunan berbahasa; (3) mendeskripsi dan menelaah strategi penutur dalam mewujudkan kesantunan berbahasa yang terdapat dalam Para Priyayi karya Umar Kayam. Pendekatan penelitian yang dipakai adalah pendekatan pragmatik, yakni mempelajari strategi-strategi yang ditempuh penutur dalam mengomunikasikan maksud pertuturannya. Metode analisis yang dipakai adalah metode kontekstual, yakni analisis yang mendasarkan, memperhitungkan, dan mengaitkan bahasa dengan identitas-identitas konteks penggunaannya. Simpulan penelitian ini mencakup tiga hal. Pertama, tindak tutur dalam novel Para Priyayikarya Umar Kayam terdiri atas tindak tutur yang terbagi dalam lima kelompok tindak ilokusi, yakni representatif, direktif, komisif, ekspresif, dan isbati [2].

Tulisan lainnya yang relevan dengan kesantunan berbahasa dalam artikelnya yang berjudul "Kesantunan Berbahasa ditinjau dari Perspektif kecerdasan Majemuk". Tulisan ini mencoba mendeskripsikan second - order politeness dengan fokus pada hubungan antara kesantunan dengan kecerdasan dari prespektif teori kecerdasan majemuk atau multiple intelligences yang dikemukakan oleh Howard Gardner. Implikasi atas analisis terhadap paduan dua teori tersebut dibahas, terutama berkaitan dengan peran kesantunan dalam mendukung kesuksesan hidup seseorang [3].

Sage Journal membuat tuliasan yang berjudul "Politeness Strategies Used in Text Messaging: Pragmatic Competence in an Asymmetrical Power Relation of Teacher-Student". Penelitian ini berusaha untuk menggambarkan strategi yang digunakan oleh kedua kelompok yaitu laki-laki dan perempuan untuk mengetahui apakah ada perbedaan yang signifikan antara bahasa Inggris pria dan wanita sebagai pelajar bahasa asing (EFL) di penggunaan strategi kesopanan positif dan negatif dalam mengirim SMS ke profesor mereka, mengingat bahwa ada hubungan kekuatan asimetris dan jarak sosial di antara mereka. Untuk tujuan ini, korpus 300 L1 (Persia) dan L2 (Bahasa Inggris) meminta pesan dikompilasi. Hasil analisis data kualitatif dan 
kuantitatif menunjukkan tidak ada perbedaan yang signifikan antara kedua kelompok. Hasil penelitian memiliki implikasi dalam penelitian kesopanan [4].

Kesantunan berbahasa juga diteliti sebagai tesis dengan judul "Kesantunan Berbahasa Mahasiswa dalam Berinteraksi di Lingkungan Universitas Tidar Kajian Sosiopragmatik" Penelitian ini bertujuan untuk mendeskripsikan jenis tindak tutur berbahasa mahasiswa, pematuhan kesantunan berbahasa, pelanggaran kesantunan berbahasa dan faktor penyebab terjadinya kesantunan berbahasa mahasiswa dalam berinteraksi di lingkungan Universitas Tidar. Penelitian ini merupakan penelitian naturalistic dengan dua pendekatan yaitu pendekatan teoretis ( pendekatan pragmatic) dan pendekatan metodologis (deskripsi kualitatif). Sumber data yang digunakan adalah sumber lisan yang berupa tuturan-tuturan pada peristiwa tutur di lokasi penelitian. Data penelitian berupa penggalan tuturan kesantunan berbahasa mahasiswa. Metode dan teknik pengumpulan data menggunakan metode simak. Teknik padan yang digunakan untuk mencocokkan daya yang telah diperoleh dengan aturan-aturan atau norma yang berpedoman pada kriteria prinsip kesantunan. Teknik penyajian hasil analisis data dibagi menjadi dua yaitu penyajian data informal dan penyajian data formal. Hasil peneliatian ini yaitu pertama, tindak tutur yang dilakukan oleh mahasiswa dalam berinteraksi di lingkungan Universitas Tidar berupa tindak tutur representative, tindak tutur direktif, tindak tutur ekspresif (evaluative), tindak tutur komisif, dan tindak tutur deklarasi (isbati). Kedua pengukuran tingkat kesantunan berbahasa mahasiswa di lingkungan Universitas Tidar didasarkan pada pematuhan prinsip kesantunan berupa bidal ketimbangrasaan, bidal kemurahatian, bidal keperkenaan, bidal kerendahhatian, bidal kesetujuan dna bidal kesimpatian. Ketiga pelanggaran prinsip kesantunan digunakan untuk mengukur tingkat kekurangsantunan pada tindak tutur mahasiswa dalam berinteraksi berupa bidal ketimbangrasaan, bidal kemurahatian, bidal keperkenaan, bidal kerendahhatian, bidal kesetujuan dna bidal kesimpatian. Keempat faktor penyebab kesantunan bebahasa dipengaruhi oleh kebutuhan berinteraksi antara lain yaitu terdapat lima faktor diantaranya tempat dan suasana tutur, peserta tutur, tujuan tutur, pokok tuturan, dan sarana tutur [5].

Dari penelitian-penelitian yang sudah dijabarkan di atas, penelitian ini berbeda dari segi permasalahan yang dikaji, yaitu pematuhan prinsip kesantuan, pelanggaran prinsip kesantunan, dan strategi pemenuhan prinsip kesantunan yang digunakan Dalang Tegalan dalam pementasan wayang purwa. Sumber data dalam penelitian ini juga berbeda dari penelitian sebelumnya, yaitu tuturan yang digunakan dalang dalam pementasan wayang purwa.

Tujuan dari penelitian ini adalah sebagai berikut. (1) Menganalisis pelanggaran prinsip kesantunan tuturan Dalang Tegalan dalam limbukan pada pementasan wayang purwa. (2) Menganalisis pematuhan prinsip kesantunan tuturan yang digunakan Dalang Tegalan dalam limbukan pada pementasan wayang purwa. (3) Menganalisis strategi kesantunan yang digunakan dalam tuturan Dalang Tegalan dalam limbukan pada pementasan wayang purwa.

\section{METODOLOGI PENELITIAN}

Penelitian ini merupakan penelitian kualitatif deskriptif. Penelitian kualitatif deskriptif menurut Sugiyono, 2015: 209, yakni penelitian yang bertujuan untuk mengeksplorasi dan atau memotret situasi sosial yang akan diteliti secara menyeluruh, luas dan mendalam [6]. Dikatakan penelitian kualitatif karena berkaitan dengan data penelitian yang bukan berupa angka-angka, tetapi berupa kualitas bentuk verbal yang berwujud tuturan. Sumber data dalam penelitian ini adalah tuturan Dalang Tegalan dalam limbukan pada pementasan wayang purwa. Data dalam penelitian ini berupa tuturan yang diduga mematuhi melanggar kesantunan berbahasa beserta konteksnya, dan tuturan tersebut nantinya akan ditranskripsi ke dalam bentuk tulisan. Sumber data dalam penelitian ini yaitu tuturan Dalang Tegalan Ki Enthus Susmono dengan pertimbangan Ki Enthus terkenal sebagai dalang edan dari kota Tegal dan tuturannya menurut berbagai sumber dikategorikan tidak sopan.

Teknik pengumpulan data merupakan langkah yang paling strategis dalam penelitian, karena tujuan utama dari penelitian adalah mendapatkan data. Dalam penelitian ini digunakan metode simak dengan teknik catat yang tergolong dalam studi dokumen berbentuk video. Bicara, 
sebagai praktik penggunaan bahasa yang paling alamiah dikenal lewat pendengaran. Jika bicara itu didengarkan dengan penuh kesungguhan - seperti dalam kerangka penelitian secara linguistis - maka dikatakan bicara itu disimak [7], sedangkan teknik catat merupakan salah satu bentuk pengumpulan data yang merupakan teknik lanjutan dari metode simak. Data yang diperoleh bersumber dari video (tayangan) pementasan wayang purwa. Pertama, penulis menyimak tayangan tersebut dengan seksama untuk mencari data-data berupa tuturan limbukan yang melanggar prinsip kesantunan berbahasa. Kemudian, tuturan tersebut dicatat untuk selanjutnya dilakukan analisis. Teknik catat menggunakan tabel data untuk menganalisis penggalan tuturan yang telah ditranskripsikan dalam bentuk kartu data.

Data yang telah terkumpul dianalisis sesuai dengan tujuan penelitian ini. Analisis dalam penelitian ini dilakukan melalui dua prosedur, yaitu: (1) analisis selama proses pengumpulan data, dan (2) analisis setelah pengumpulan data. Prosedur pertama dilakukan dengan langkah-langkah: (1) reduksi data, (2) sajian data, (3) pengambilan simpulan. Prosedur kedua dilakukan dengan langkah-langkah: (1) transkripsi data hasil pencatatan, (2) pengelompokkan data yang berasal dari pencatatan berdasarkan bentuk pematuhan dan pelanggaran kesantunan, (3) penafsiran/penjelasan bentuk pematuhan dan pelanggaran kesantunan.

\section{HASIL DAN PEMBAHASAN}

\section{Hasil Penelitian}

\section{Pelanggaran prinsip kesantunan tuturan dalang Tegalan dalam limbukan pada pementasan wayang purwa}

Dalam limbukan, dalang ingin menyampaikan nasihat-nasihat yang disampaikan dengan cara yang lucu bahkan cenderung vulgar. Karena tujuannya memberikan nasihat, tidak semua prinsip kesantunan dilanggar. Dari hasil penelitian, hanya beberapa bidal saja yang terdapat pelanggaran prinsip kesantunan seperti dalam tuturan berikut.

Bidal Ketimbangrasaan

Tuturan 1

Percakapan antara Semar, Gareng, Petruk, dan Bagong.

Bagong: Jaman saiki kudu dibaleke hakikat sing tenanan. Kowe madepe mrana....

Gareng: Yo asu....

Semar : Njenengan wonten inggil.

Gareng: Wah aku pekewuh iki.

Petruk : Nek perlu dielus-elus.

Gareng: Ora kuwalat?

Petruk: Gak...wong tuwa ngemban anake nangis...nguyuh...wah, pinter nemen anakku nguyuh....

Bagong: Yen perlu uyuhana Semar.

Petruk : Huss...

Gagasan dasar bidal ketimbangrasaan dalam prinsip kesantunan adalah bahwa pihak lain di dalam tuturan hendaknya dibebani biaya seringan-ringannya tetapi dengan keuntungan sebesarbesarnya. Kalimat yang dicetak miring yang diucapkan Bagong dan Semar kepada Petruk membuat Petruk merasa pakewuh (tidak enak sendiri). Hal ini merupakan pelanggaran prinsip kesantunan yang dilakukan oleh Semar dan Bagong.

Tuturan 2

Percakapan antara Semar, gareng, dan Petruk.

Semar : Eh thole Gareng....ning sajroning sasi Syawal iki aku sebagai wong tuwa njaluk pangapura sing akeh.

Gareng : Apa rak kwalik ki.

Petruk : Sik... Rama Semar mesthi duwe alesan. Padha kyai-kyai sing kudu njaluk pangapapura kalih santri sebab santri takdzim karo kyai...

Kalimat yang dicetak miring di atas juga melanggar bidal ketimbangrasaan karena menyuruh para kyai untuk meminta maaf kapada para santrinya. 
Bidal Keperkenaan

Tuturan 3

Percakapan antara Petruk dan Bagong.

Petruk :Kenapa kok sangsaya sangsara.... apa-apa sak sangsaya mundhak.

Bagong: Mergane pejabate ora duwe niyat. Nek barang wis lungguh lali karo sing milih.

Bidal keperkenaan berisi nasihat bahwa orang akan dianggap santun apabila dalam bertutur selalu berusaha memberikan penghargaan atau pujian kepada pihak lain dan meminimalkan penjelekan terhadap pihak lain. Dengan bidal ini diharapkan para peserta tutur tidak saling mengejek, saling mencaci, atau saling merendahkan pihak lain. Dalam tuturan di atas terdapat pelanggran bidal keperkenaan karena menjelekkan pejabat yang dianggap menyebabkan semua kesengsaraan rakyat.

Tuturan 4

Percakapan antara Semar, Petruk, dan Bagong.

Semar :Wong tuwa sing conthone Dalang Narso... mlarate kaya ngapa karo anake ngopeni. Wingi lebaran wae anake diseragaman.

Petruk : Nganggo batik?

Semar : keramenan.

Petruk : Nganggo lurik?

Semar : kelurusen.

Bagong: Nganggo jas?

Semar : Keresminen. Anakke Narso diseragam ora klamben kabeh.

Kalimat bercetak miring di atas merupakan pelanggaran bidal keperkenaan karena menjelekkan Narso yang tidak sanggup membelikan anaknya baju sehingga anaknya seragam tidak memakai baju semua ketika lebaran.

Tuturan 5

Percakapan dalang dan sindennya yang bernama Meghan.

Dalang : Ya crazy tadi. Mereka suka sama orang-orang gila karena mereka juga gila.

Meghan: iya kayanya ya.

Dalang : Ya kumpulan wong edan.

Meghan: edan kabeh.

Dalang : Termasuk raemu ya edan. Genah wong edan dikinthil.

Pelanggaran bidal keperkenaan terdapat dalam tuturan di atas karena dalang mengatakan gila kepada orang-orang yang menyukai dirinya. Termasuk sinden (Meghan) juga gila karena sudah tahu dalangnya gila namun tetap diikuti.

Bidal Kerendahhatian

Tuturan 6

Percakapan antara dalang dan sindennya yang bernama Meghan.

Meghan: Pak Dalang...iki penontonnya luar bisa dalam karir saya di Jawa. Saya belum pernah lihat seperti ini. yang lain.

Dalang :Kalau dalang-dalang lain gak begini ini. Soalnya saya memang lain daripada

Dalam bidal kerendahhatian, peserta tutur diharapkan dapat bersikap rendah hati dengan cara meminimalkan pujian terhadap diri sendiri dan memaksimalkan penjelekan kepada diri sendiri. Orang akan dikatakan tidak santun apabila di dalam kegiatan bertutur selalu memuji dan mengunggulkan diri sendiri. Bidal ini bertujuan untuk merendahkan hati agar tidak sombong bukan untuk merendahkan diri. Dalam percakapan di atas, kalimat bercetak miring merupakan pelanggaran bidal kerendahhatian karena dalang memuji dirinya sendiri.

Pematuhan prinsip kesantunan tuturan dalang Tegalan dalam limbukan pada pementasan wayang purwa

Bidal Kemurahhatian

Tuturan 7

Percakapan antara Semar dan Gareng. 
Semar :Eh thole Gareng....ning sajroning sasi Syawal iki aku sebagai wong tuwa njaluk pangapura sing akeh.

Gareng : Apa rak kwalik ki.

Tuturan yang dituturkan Semar mematuhi bidal kerendahhatian karena Semar sebagai orang tua tidak segan untuk meminta maaf terlebih dahulu kepada anaknya, Gareng. Dengan bidal kemurahhatian, penutur diharapkan dapat menghormati orang lain. Penghormatan terhadap orang lain akan terjadi apabila orang dapat mengurangi keuntungan pada dirinya sendiri dan memaksimalkan keuntungan bagi pihak lain.

Bidal Keperkenaan

Tuturan 8

Percakapan antara Semar dan Gareng.

Semar :Aku iki rumangsa dosa gedhe karo kowe jalaran aku sing tuwa durung tau mbahagiake kowe. Iki kowe dadi calon wakil bupati kudu tanggung jawab sing paling gedhe. Kudu menang kowe. Maka aku njaluk pangapura nek kowe wis cetha. Bisa nggawe senengku. kontol.

Gareng :Nyuwun pangapunten Rama. Mboten mbekta napa-napa. Kula mung mbekta

Semar : Sing baku kuwi salamane. Sing baku kuwi sowane. Yo nek anak ana. Lha wong kulo ngertos kalih sampeyan. Nggo nggaglak wae ora ana, nggo tuku rokok meneh. Aku njaluk pangapura kowe wis tau nggawe enake wong tuwa. Mula syareat anak bisa kuwalat karo wong tuwa. Ning hakikat ana wong tuwa sing ora ngurusi anak kuwi wong tuwa sing keparat. Wong tuwa sing conthone Dalang Narso... mlarate kaya ngapa karo anake ngopeni. Wingi lebaran wae anake diseragaman.

Dalam tuturan di atas terdapat pematuhan bidal keperkenaan yaitu memuji orang lain. Hal tersebut ditunjukkan oleh Petruk yang sudah membahagiakan (membuat senang) Semar. Dalam tuturan berikutnya Semar juga memuji Dalang Narso yang menurutnya meskipun miskin namun terhadap anak memperhatikan. Buktinya ketika lebaran anaknya dipakaikan seragam.

Tuturan 9

Percakapan dalang dengan sindennya (Meghan).

Dalang :Mbak Meghan...lancar sekali Bahasa Indonesianya.

Meghan :Oh lumayan...sedikit-sedikit...saya suka belajar...

Dalang :Tapi banyak koh...tidak sedikit.

Tuturan di atas yang bercetak miring menyatakan dalang mematuhi bidal keperkenaan. Dalang memuji sinden (Meghan) yang meskipun berasal dari Amerika namun dia lancar berbahasa Indonesia. Selain itu kosakata Bahasa Indonesia yang dikuasi Meghan menurut dalang sudah banyak.

Bidal Kerendahhatian

Tuturan 10

Percakapan antara Semar dan Gareng

Semar :Eh thole Gareng....ning sajroning sasi Syawal iki aku sebagai wong tuwa njaluk pangapura sing akeh.

Gareng : Apa rak kwalik ki.

Tuturan yang dituturkan Semar mematuhi bidal kerendahhatian karena Semar sebagai orang tua tidak segan untuk meminta maaf terlebih dahulu kepada anaknya, Gareng.

Tuturan 11

Percakapan antara dalang dan sindennya (Meghan).

Dalang :Mbak Meghan...lancar sekali Bahasa Indonesianya.

Meghan :Oh lumayan... sedikit-sedikit...saya suka belajar...

Dalam tuturan di atas bidal kerendahhatian ditunjukkan oleh tuturan Meghan yang menganggap Bahasa Indonesia yang dikuasainya sedikit dan dia mengakui kalau suka belajar.

Tuturan 12

Percakapan antara Bagong dan Gareng.

Bagong : Mergane pejabate ora duwe niyat. Nek barang wis lungguh lali karo sing milih.

Gareng :Oh, ngono. Kowe aja nyalahke pejabat. Sing salah adalah kita semua. 
Pematuhan bidal kerendahhatian juga ditunjukkan dalam tuturan Gareng yang menyatakan kalau yang salah adalah 'kita semua'. Gareng mengingatkan Bagong supaya jangan menyalahkan pejabat.

Tuturan 13

Percakapan antara Subali dan Petruk. Subali baru saja bertarung melawan butho (raksasa).

Subali : Lah piye....

Petruk : Sakgedhen-gedhene wayang tetep kalah karo dalang.... wong dalang sing nglakoke kok...

Pematuhan bidal kerendahhatian dituturkan oleh Petruk. Petruk mengingatkan Subali bahwa sebesar apapun wayang (seperti butho) akan tetap kalah dengan dalang. Karena sejatinya yang menjalankan wayang adalah dalang.

\section{Strategi kesantunan yang digunakan dalam tuturan dalang Tegalan dalam limbukan pada pementasan wayang purwa}

Wayang purwa, sebagai salah salah satu kebudayaan Jawa di dalamnya juga mengajarkan hal yang berkaitan dengan kesantunan. Ki Enthus Susmono sebagai Dalang Tegalan juga menyampaikan nasihat-nasihatnya dalam limbukan dengan mematuhi bidalbidal di atas yaitu kurmat, andap asor, empan papan, dan tepa slira. Ki Enthus Susmono terkenal sebagai dalang edan (gila), dan ini dibuktikan dalam penggunaan bahasa yang vulgar, contohnya dalam tuturan berikut.

Bagong: Kowe ki asu tenan jan, aja saru-saru... kontol.

Gareng : Nyuwun pangapunten Rama. Mboten mbekta napa-napa. Kula namung mbekta

Pemakaian kata-kata seperti tuturan di atas untuk masyarakat Indonesia umumnya tergolong vulgar, namun untuk masyarakat Tegal hal tersebut biasa saja. Pemakaian bahasa yang demikian memang dimaksudkan supaya apa yang ingin disampaikan dalang dapat dipahami dengan jelas. Namun, meskipun disampaikan secara vulgar dalang tetap mematuhi strategi kesantunan dalam budaya Jawa seperti yang diterangkan di atas. Strategi tersebut seperti dalam tuturan berikut.

Kurmat

Percakapan antara Semar (Bapak) dan Gareng (anak)

Semar :Njenengan wonten inggil.

Gareng : Wah aku pekewuh iki.

Tuturan Semar yang menyuruh Gareng untuk di atas sedangkan dia di bawah membuat tidak enak hati Gareng. Sebagai anak, Gareng yang seharusnya berada di bawah sebagai tanda hormat kepada orang tua.

Andhap asor

Percakapan dalang dan sindennya (Meghan) yang berasal dari Amerika.

Dalang :Mbak Meghan...lancar sekali Bahasa Indonesianya.

Meghan :Oh lumayan...sedikit-sedikit...saya suka belajar...

Dalang :Tapi banyak koh...tidak sedikit.

Tuturan dalang yang memuji Meghan yang berasal dari luar Indonesia namun lancar dalam berbahasa Indonesia ditanggapi Meghan dengan rendah hati. Meghan menuturkan baru sedikit yang dia kuasai.

Empan papan

Petruk : Sik... Rama Semar mesthi duwe alesan. Padha kyai-kyai sing kudu njaluk pangapapura kalih santri sebab santri takdzim karo kyai... ning nek kyai memanfaatkan santri. Apa maneh nek ana pemilihan bupati. Mulane sing apik kyai duwe santri sing manfaat... ora malah kyai sing manfaatke santri.

Tuturan Petruk di atas mencontohkan kedudukan kyai dan santri. Walaupun santri dididik oleh kyai, kyai tidak semestinya memanfaatkan santri. 


\section{Pembahasan}

Hasil penelitian menunjukkan bahwa pelanggaran prinsip kesantunan oleh Dalang Tegalan dalam limbukan pada pementasan wayang purwa antara lain pada bidal: (1) ketimbangrasaan, (2) keperkenaan, dan (3) kerendahatian. Pematuhan prinsip kesantunan oleh Dalang Tegalan dalam limbukan pada pementasan wayang purwa antara lain pada bidal : (1) kemurahhatian, (2) keperkenaan, dan (3) kerendahhatian.

Prinsip kesantunan itu berkenaan dengan aturan tentang hal-hal yang bersifat sosial, estetis, dan moral di dalam bertindak tutur. Alasan diterapkannya prinsip kesantunan adalah bahwa di dalam tuturan penutur tidak cukup hanya dengan mematuhi prinsip kerja sama. Prinsip kesantunan diperlukan untuk melengkapi prinsip kerja sama dan mengatasi kesulitan yang timbul akibat penerapan prinsip kerja sama. Pelanggaran prinsip kerja sama adalah bukti bahwa di dalam berkomunikasi kebutuhan penutur (dan tugas penutur) tidaklah untuk menyampaikan informasi saja, tetapi lebih dari itu. Di samping untuk menyampaikan amanat, kebutuhan (dan tugas) penutur adalah menjaga dan memelihara hubungan sosial-pendengar.

Dari beberapa konsep kesantunan yang dikemukakan para ahli, menurut Rahardi bahwa prinsip kesantunan yang sampai dengan saat ini dianggap paling lengkap, paling mapan, dan relatif paling komperhensif adalah prinsip kesantunan yang dirumuskan oleh Leech (1983). Prinsip kesantunan yang meliputi enam bidal, yaitu (a) bidal ketimbangrasaan (tact maxim), (b) bidal kemurahhatian (generosity maxim), (c) bidal keperkenaan (appobation maxim), (d) bidal kerendahhatian (modesty maxim), (e) bidal kesetujuan (agreement maxim), dan (f) bidal kesimpatian (symphaty maxim) [8].

Bidal ketimbangrasaan dijabarkan lagi dalam subbidal, yaitu "Minimalkan biaya kepada pihak lain!" dan "Maksimalkan keuntungan kepada pihak lain!" Bidal kemurahhatian dijabarkan lagi dalam dua subbidal, yaitu "Minimalkan keuntungan pada diri sendiri!" dan "Maksimalkan keuntungan kepada pihak lain!" Bidal keperkenaan dijabarkan dalam subbidal, yaitu "Minimalkan penjelekan kepada pihak lain!" dan "Maksimalkan pujian kepada pihak lain." Bidal keperkenaan dijabarkan dalam subbidal, yaitu "Minimalkan pujian terhadap diri sendiri!" dan " Maksimalkan penjelekan terhadap diri sendiri!" Bidal ini dijabarkan dalam subbidal "Minimalkan ketidaksetujuan antara diri sendiri dan pihak lain!" dan "Maksimalkan kesetujuan antara diri sendiri dan pihak lain!" Bidal kesimpatian dijabarkan dalam dua subbidal, yaitu 1) minimalkan antipati antar diri sendiri dan pihak lain, dan 2) maksimalkan simpati antar diri sendiri dan pihak lain.

Strategi kesantunan yang dilakukan Dalang Tegalan dalam penelitian menunjukan antara lain: (1) kurmat, (2) andhap asor, dan (3) empan papan. Realisasi tindak kesantunan berbahasa dapat diungkapkan melalui dua strategi, strategi kesantunan positif dan strategi kesantunan negatif. Strategi kesantunan positif mengedepankan bagaimana kita sudah semestinya dan seharusnya menghormati orang lain. Sebaliknya, strategi kesantunan negatif lebih didasarkan pada bagaimana kita menghormati orang lain supaya orang lain itu menghargai kita. Jadi, strategi kesantunan positif dasarnya ketulusan. Sebaliknya, strategi kesantunan negatif basisnya ketidaktulusan [9].

Berkaitan dengan skala kesantuan, orang Jawa percaya akan perlunya keseimbangan untuk kelangsungan hidup. Sumber keseimbangan orang Jawa adalah asas kerukunan atau harmoni. Prinsip kerukunan dan harmoni kehidupan orang Jawa ini dapat direalisasikan ke dalam empat bidal. Keempat bidal tersebut, yaitu: (a) kurmat 'hormatilah orang lain', (b) andhap asor 'berendahhatilah', (c) empan papan 'sadarilah tempatmu', dan (d) tepa slira 'jangan lakukan kepada orang lain apa yang kamu tidak mau orang lain melakukan kepadamu'.

\section{SIMPULAN}

Dapat disimpulkan dari hasil penelitian, pelanggaran prinsip kesantunan oleh Dalang Tegalan dalam limbukan pada pementasan wayang purwa antara lain pada bidal: (1) 
ketimbangrasaan, (2) keperkenaan, dan (3) kerendahatian. Pematuhan prinsip kesantunan oleh Dalang Tegalan dalam limbukan pada pementasan wayang purwa antara lain pada bidal : (1) kemurahhatian, (2) keperkenaan, dan (3) kerendahhatian. Strategi kesantunan yang dilakukan Dalang Tegalan antara lain: (1) kurmat, (2) andhap asor, dan (3) empan papan.

\section{REFERENCES}

[1] Utami, I.G.A.L.P \& Myartawan, I.P.N.W, "Pengaruh Usia dan Strategi Berbahasa: Pragmatik tentang Kesantunan Berbahasa pada Para Penutur Bahasa Indonesia”. Jurnal Penelitian dan Pengembangan Penddikan, Vol 4, No. 3, 2010.

[2] Alviah, I, "Kesantunan Berbahasa dalam Tuturan Novel Para Priyayi Karya Umar Kayam". Jurnal Seloka Unnes, Vol. 3, No. 2, pp. 128-135, 2014.

[3] Kuntarto, E, "Kesantunan Berbahasa Ditinjau dari Perspektif Kecerdasan Majemuk". Jurnal Ilmiah Universitas Batanghari Jambi, Vol. 16, No. 2, pp. 1-16, 2016.

[4] Eshghinejad, S.dan Moini, M.R, "Politeness Strategies Used in Text Messaging: Pragmatic Competence in an Asymmetrical Power Relation of Teacher-Student". Sage Journal, January-March, pp. 1-13, 2016.

[5] Cahyani, D.N, "Kesantunan Berbahasa Mahasiswa dalam Berinteraksi di Lingkungan Universitas Tidar Kajian Sosiopragmatik”. 2016. Tesis. Unnes.

[6] Sugiyono, 2015, Metode Penelitian Pendidikan (Pendekatan Kuantitatif, Kualitatif dan $R \& D)$, Bandung: Alfabeta.

[7] Sudaryanto, 2015, Metode dan Aneka Teknik Analisis Bahasa, Jogjakarta: Duta Wacana University Press.

[8] Prayitno, H.J.P, 2014, Perwujudan Tindak Kesantunan Direktif Siswa SD Berlatar Belakang Budaya Jawa, dalam Prosiding Ketidaksantunan Berbahasa dan Dampaknya dalam Pembentukan Karakter, Surakarta :Balai Bahasa Universitas Muhammadiyah Surakarta.

[9] Rahardi, Kunjana, 2005, Pragmatik Kesantunan Imperatif Bahasa Indonesia. Jakarta: Erlangga. 